\title{
The Impact of Performance Appraisal on Employee Performance in Banks Operating in the South of Jordan
}

\author{
Dr. Arwa Hisham Rahahleh \\ Al-Hussein Bin Talal University, \\ P.O. Box 20 Ma'an, Jordan \\ E-mail: aaarawaa@yahoo.com
}

Dr. Zaid Ahmad Alabaddi

Al-Hussein Bin Talal University, P.O. Box 20 Ma'an, Jordan

E-mail: zaid.abaddi@yahoo.com

Dr. Monira Abdallah Moflih

The World Islamic Science \& education university

E-mail: Muflehk@yahoo.com

Received: Aug. 22, 2019 Accepted: Sep. 22, 2019 Online published: Oct. 21, 2019

doi:10.5296/ijhrs.v9i4.15317 URL: https://doi.org/10.5296/ijhrs.v9i4.15317

\begin{abstract}
This research was about performance appraisal and its effect on employees' work performance. The major aim of the research was to investigate the effect of performance appraisal on employees' work performance of banks in the South of Jordan. This study also aimed at investigating the major elements of performance appraisal which included: establishing performance standards, establishing communication standards, measuring actual performance with established standards, discussing the appraisal with employees and giving feedback. In conducting this study, the required data was collected through a closed ended structured questionnaire. The questionnaire was adopted and adapted from many related studies. The procedures used to determine the comprehensive sample from a total population of 260 employees was the following: First, the target population was identified; second, the researcher used a formula based-sample size determination. Basically, a total of 260 questionnaires were distributed to the sampled employees and 260 were returned which represented a $100 \%$ response rate. The 260 returned questionnaires were then analyzed using smart PLS which is specially used for Structural Equation Modeling, path analysis, and confirmatory factor analysis. It is also known as analysis of covariance or causal modeling software. A descriptive statistics and correlation analysis was performed.
\end{abstract}


The results of the study showed that performance appraisal has a mainly positive effect on employee performance in the banking sector of the South of Jordan. There correlation analysis showed that there was a positive and some negative association (Very strong association) between performance appraisal and employee performance.

Keywords: performance appraisal, employee performance, work performance

\section{Introduction}

Performance assessment is considered the most important human resource activity that is used to assist and develop the current performance of the staff by supervisors (Jabeen ,2011). Armstrong (2006) assessed the role of performance appraisal as a tool to meet new challenges in the organization. Daoanis (2012) discussed the importance of performance evaluation's role in the organization in ensuring that employees perform their assigned work according to the required standards. Employee compensation and incentives are also tied to performance evaluation. Evaluating and assessing employee and staff performance is one of the most common practices in most organizations. (Karimi, Malik and Hussain, 2011). This research was divided into five main sections: the first section consisted of background research about the variables, the second section consisted of the conceptual framework, the third section consisted of the theoretical framework, the fourth section consisted of the research methodology and data analysis, and the last section consisted of the conclusion and recommendations.

\subsection{Background of the Study}

In his study Sajuyigbe and Ademola (2017) stated that many organizations are experiencing low productivity because they are not well managed by PAS (performance appraisal system). Training requirements can only be determined through performance evaluation results. PAS is an alternative model for high productivity and performance. Consequently, the study examined the impact of PAS on employee performance in the telecommunications sector. Simple random sampling method was used to select sixty-five persons out of a total population of 1,300 $(1,300)$ in MTN, Nigeria. The results of the survey were used as basis for personal interviews. Data analysis was performed with the help the of mean, standard deviation and linear regression. The results of the study revealed that the level of awareness among employees of performance evaluation is high. The results also proved that PAS has a high impact on staff performance. Further, the results also revealed that the lack of timely feedback hindered the performance appraisal system in MTN, Nigeria. The author recommended that evaluation of employees by management should be objective and transparent in the organization. There should also be feedback and career development in order for the organization to develop a competitive advantage in this area.

Khan, saha and pal (2018), the aim of the study was to identify the relationship between performance evaluation and employee performance to obtain empirical results on this type of relationship in higher education institutions in Pakistan. The researcher used a survey-based questionnaire. Data was collected from 150 respondents in public sector universities in Khyber Pakhtunkhwa through a self-administered questionnaire. 300 questionnaires were distributed to faculty members at public sector universities in Khyber Pakhtunkhwa, Pakistan, of which 150 were returned and with a response rate 50\%. The results of this study revealed that there is a positive correlation between performance assessment and employee performance in public sector universities in Khyber Pakhtunkhwa, Pakistan. The evaluation of the performance of the universities was fair and this will encourage employees to enhance their skills and improve their performance individually and organizational performance in 
general. The importance of this study is that researchers can learn from policymakers in higher education.

Girma, solomon and gebre (2016). The aim of the study was to explore the impact of the performance evaluation process on the performance of staff members of Hawass University faculty. Data was collected through the distribution of structured questionnaires to 320 tenured administrative staff. The results of this study showed that there is a positive relationship between the independent and consequential variables. As a result, performance standards were established and the employees were informed of these standards. These performance standards were then developed and the actual performance of the employees was measured against these new standards. The employees' performance met these standards and then management discussed the evaluation of employees regarding these standards. Employees were free to express their opinions regarding these standards and corrective action was taken based on this information. As a result, the university's administration should make some improvements because of the evaluation system

Agyare et al. (2016) Performance evaluation is a key element that motivates employees in the organization to achieve their organizational goals. The researcher conducted a study showing the effects of performance evaluation on job satisfaction and employee commitment. A descriptive research was used in the study, where 200 samples were taken from a microfinance institution in Ghana using random sampling. A questionnaire was used as data collection tool. The study revealed that a fair employee evaluation by management positively affects employee satisfaction. The researcher links the positive ratings to promotions and clarifies the role of the staff and the comments directed at them about their performance. The study also revealed that linking salary and compensation assessments, identifying training needs, employee knowledge of evaluation skills, and engaging staff in the formulation of assessment tools positively affects their job commitment. The researcher recommended that organization increase salaries according the levels of performance of the staff, and to conduct training programs for employees who need it in order to know the importance of performance evaluation and motivate employees to reach their organizational goals and increase communication between management so employees can be aware of their performance.

\section{Conceptual Framework}

The conceptual framework includes six sections which are: the problem statement, the research contribution, the research objectives, the research question, the research hypothesis, and the conceptual model.

\subsection{Statement of the Problem}

Because of its effect on employee performance, Performance appraisal plays a vital role in all organizations especially in the banking sector. Performance appraisal is very important in all organizations that evaluate staff according to the tasks that they perform in order to ensure employees perform their job as required. In this paper the researcher investigated the relation between performance appraisal and employee performance. The study sought to identity if performance appraisal has a positive impact on employees' performance when this appraisal is well conducted.

\subsection{Research Contribution}

This study is going to contribute immensely to existing knowledge on the study of Performance appraisals. The study aimed at investigating the impact of Performance Appraisals on employees' performance with a focus on the finance sector of banks in the 
South of Jordan.

The study should contribute to the development of banking and financial sectors which plays a significant role in the economy of South of Jordan specifically and in Jordan in general. In spite of the many challenges it faces, the banking sector has emerged nationally and globally as effective at strategies that evaluates employee performance. The banking sector is also one of the most important sectors because it desires to provide a high level of quality of service. Banking sector employees achieved a high level of quality of service because of performance appraisal. This study will also serve as a source of reference for other related research works in the future. The factors that were identified by the research will be very useful.

\subsection{Research Objectives}

The study's main aim is to investigate the impact of performance appraisals on employees' work performance. The study's specific objectives included investigating the relationship between performance appraisal and Employees' work performance. Furthermore, it also investigated some sub objectives which included;

1. To investigate the relation and the impact of performance appraisal on employee work performance.

2. To investigate the relation and the impact of establishing performance standards on employee work performance.

3. To investigate the relation and the impact of established communication standards on employee work performance.

4. To investigate the relation and the impact of measuring actual employee performance and

comparing it with standards.

5. To investigate the relation and the impact of corrective action on employee work performance.

6. To provide suggestions and recommendations to improve employee performance.

\subsection{Research Questions}

In the light of the above mentioned objectives, the study sought to answer the following research questions:

1. What is the impact of employees work performance, and performance appraisal?

2. What is the impact of establishing performance standards on employee work performance?

3. What is the impact of established communication standards on employee work performance?

4. What is the impact of measuring actual employee performance and

Comparing it with standards?

5. What is the impact of corrective action on employee work

Performance? 


\subsection{Research Hypotheses}

H01: There is a negative impact on employees work performance by performance appraisal with significance of $5 \%$

H02: There is a negative impact of establishing performance standards on employee work performance with a significance of $5 \%$.

H03: There is a negative impact of established communication standards on employee work performance with a significance of $5 \%$.

H04: There is a negative impact of measuring actual employee performance and

Comparing it to standards with a significance of $5 \%$.

H05: There is a negative impact of corrective action on employee work performance with a significance of $5 \%$.

\subsection{The Conceptual Model}

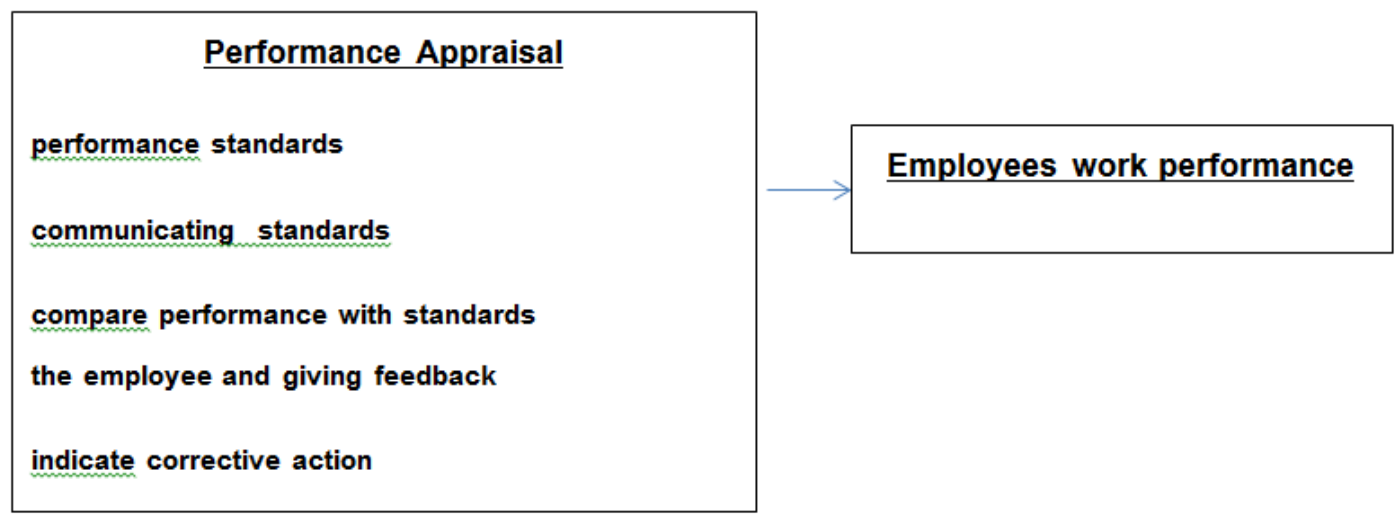

\section{Scope of the Study:}

This study focuses of the effect of performance appraisal on employee performance in the banking sector in the South of Jordan including (Maan, Karak, Tafeeleh, Aqaba) the study population is 260 employees working in the banking sector in the South of Jordan.

\section{Study Limitation:}

The major limitation of this study is the limited number of literature on the subject and the limited access to different data bases.

\section{Literature Review}

This section consists of three sections: performance appraisal, performance appraisal process, and the importance the performance appraisal.

\subsection{Performance Appraisal}

There are many definitions of Performance Appraisal, Armstrong (2006) defines performance appraisal as the official rating and classification of staff by their managers where the staff is 
usually assessed annually. Furthermore, Performance evaluation is the management's practice of identifying and measuring staff performance in organizations (Gomez, david and robert 2001).Also, Performance assessment provides assistance to employees in determining their goals, future orientation, and passion to accomplish their assigned tasks (Judge \& Ilies, 2002).

Performance is what the management expects staff to deliver in terms of results, efforts, tasks and quality within a specific time frame and under certain conditions (Kumari \& Malhotra, 2012).

The researcher determined that the process of measuring employee performance is based on specific goals and expectations (Mondy and Noe, 2005: 252).Cones and Jenkins (2000) suggest that performance appraisal is a process by which employees' behavior or characteristics are categorized and the results are maintained and evaluated by the organization.

Gary (2003) defines performance as a means of assessing the current or past performance of an employee in relation to a person's performance criteria. Evaluations include: Assessing the actual performance of the employee with respect to the standards involved, developing the work standards and providing feedback to the employee in order to motivate that person to remove deficiencies. Performance evaluation is a way to assess employee behavior in an organization: an organization's assessment of the level of an individual's performance and a review of the employee's quality of performance against organizational objectives

\subsection{Performance Appraisal Process}

Managers use the performance appraisal system to enable employees to reach their organizational goals efficiently and effectively and thus maximize their potential. Performance assessment is the key tool through which staff performance can be successfully monitored. The research reveals a correlation between performance appraisal, employee wages and compensation and employee performance where these factors (favorable wages and compensation) strengthen the employee's commitment to the organization. (Gingrico et al. 2012). Foot and Hook $(2011,250)$ argue that employees must be involved in assessments, be in agreement with organizational goals, identification and integration of organizational goals with individual goals. The researcher considers performance management processes as an ongoing process of negotiation between management and staff that calls for effective communication between them to achieve organizational goals (Acuff, 2008: 6)

\subsection{The Importance of Performance Appraisal}

The process of assessing the performance of employees is an important process because it helps management understand employees within the complex organization. Furthermore, non-practical assessment structures tend to lead to frustration, discomfort and non-use. Similarly, systems that are not specifically related to the employee tasks have wasted resources and time. In fact, most successful evaluation mechanisms identify and evaluate only critical behaviors that contribute to job success (Mwema \& Gachunga .2014). The performance evaluation process is essential because it empowers the planning of employee 
performance by helping the organization achieve its business objectives and performance review in a manner that motivates employees to exploit their full potential in line with the organization's objectives (Swanepoel, erasmus \& schenk.1998).

The performance appraisal process has an impact on five important organizational outcomes: financial performance, productivity, product and service quality, customer satisfaction, and employee satisfaction. Effective performance management is recognized as the development of staff skills and abilities, improving customer service and quality of the process, achieving both financial and non-financial objectives (de Waal, 2007, p. 120). Furthermore, it is important for staff to believe that in the performance evaluations, there is a great opportunity for them to improve their work and the assessments are just (Weick \& stucliffe, 2001). Without fairness, the performance appraisal system, rewards, motivations and development have a negative impact on staff (Gilliland and Langdon, 1998).

\section{Research Methodology and Data Analysis}

The Research employed a quantitative approach to examine the effect of Performance Appraisal on employees' performance in the banking sector in Ma'an, Jordan. This research paper consists of methods that were used in establishing the effectiveness of Performance Appraisal on employee performance. These methods included the research design and approach which was a descriptive research design. The researchers aim was to determine the aspects of the problem that are crucial for analysis. A quantitative research approach was used to examine the Effect of Performance Appraisal on Employees Performance in the banking sector in Maan.

\section{Sample Size:}

The research Population was all the employees (260) working in 30 banks in the South of Jordan. The Sample was a comprehensive and included all the population of 260 employees working in banks in the South of Jordan. In order to achieve the study's objectives both primary and secondary sources of data were used. The primary source of data was a questionnaire to bank employees in the South of Jordan. The primary data was collected through questionnaire that was made up of close ended questions based on the problem statement. Data Collection Procedures, Ethical Consideration and Data Analysis were employed which are included in this section.

\section{Data Analysis and Results:}

\section{Demographic Data Results}

In terms of gender, the study population was made up of $61.5 \%$ males and $38.5 \%$ females. In terms of work experience, $49.2 \%$ had less than 5 years whilst $3.1 \%$ had more than 15 years. The largest group of respondents, totalling 52.3\%, were aged between 18 and 25 years. The smallest group totalled $4.6 \%$ and were those over 36 years. Further, $90.8 \%$ of the samples were found to have a bachelor's degree, whereas $1.5 \%$ had a secondary school education. The largest group of employees, equating to $47.7 \%$, held positions in customer service, whilst the smallest group, equating to $6.2 \%$, were branch managers. The social status of the employees 
was: $64.6 \%$ of the respondents were unmarried, whereas $35.4 \%$ were married.Table( 1 )shows a general description of the characteristics of the study sample:

Table (1). General description of the characteristics of the study sample

\begin{tabular}{|c|c|c|c|}
\hline Variables & $\begin{array}{l}\text { Variable } \\
\text { options }\end{array}$ & Frequency & percent \\
\hline \multirow{2}{*}{ Gender } & Male & 160 & $61.5 \%$ \\
\hline & Female & 100 & $38.5 \%$ \\
\hline \multirow{4}{*}{$\begin{array}{l}\text { Years of } \\
\text { Experience }\end{array}$} & $\begin{array}{l}\text { Less than } 5 \\
\text { years }\end{array}$ & 128 & $\% 49.2$ \\
\hline & $\begin{array}{l}\text { From } 5 \text { to } 10 \\
\text { years }\end{array}$ & 112 & $\% 43.1$ \\
\hline & $\begin{array}{l}\text { From } 11 \text { to } \\
15 \text { years }\end{array}$ & 12 & $\% 4.6$ \\
\hline & $\begin{array}{l}\text { More than } \\
15 \text { years }\end{array}$ & 8 & $\% 3.1$ \\
\hline \multirow{4}{*}{ Age } & $\begin{array}{l}\text { From } 18 \text { to } \\
25 \text { years }\end{array}$ & 136 & $\% 52.3$ \\
\hline & $\begin{array}{l}\text { From } 26 \text { to } \\
30 \text { years }\end{array}$ & 84 & $\% 32.3$ \\
\hline & $\begin{array}{l}\text { From } 31 \text { to } \\
35 \text { years }\end{array}$ & 28 & $\% 10.8$ \\
\hline & $\begin{array}{l}\text { Over } \\
\text { years }\end{array}$ & 12 & $\% 4.6$ \\
\hline
\end{tabular}




\begin{tabular}{|c|c|c|c|}
\hline \multirow{5}{*}{ Qualification } & $\begin{array}{l}\text { Secondary } \\
\text { school }\end{array}$ & 4 & $\% 1.5$ \\
\hline & High School & $\mathbf{0}$ & $\mathbf{0}$ \\
\hline & Diploma & 8 & $\% 3.1$ \\
\hline & Bachelor & 236 & $\% 90.8$ \\
\hline & Master & 12 & $\% 4.6$ \\
\hline \multirow{5}{*}{ Job title } & $\begin{array}{l}\text { Credit } \\
\text { Officer }\end{array}$ & 72 & $\% 27.7$ \\
\hline & $\begin{array}{l}\text { Customers } \\
\text { Service }\end{array}$ & 124 & $\% 47.7$ \\
\hline & Supervisor & 24 & $\% 9.2$ \\
\hline & $\begin{array}{l}\text { Branch } \\
\text { Manager }\end{array}$ & 16 & $\% 6.2$ \\
\hline & Other & 24 & $\% 9.2$ \\
\hline \multirow[b]{2}{*}{ Social status } & Unmarried & 168 & $\% 64.6$ \\
\hline & Married & 92 & $\% 35.4$ \\
\hline
\end{tabular}

\section{Constructs Measurements Analysis:}

The Smart Partial Least Square-Structure Equation Modelling (PLS-SEM) program was selected and used in this research in an attempt to inspect and analyze the data associated with the hypotheses. Two respective phases were concluded (Anderson and Garbing, 1988) these two phases were exploring the content, convergent and discriminate validity of dimension. There was additional data testing performed in relation to hypotheses, in configuration with the research model. 


\section{Macrothink}

\section{Path Loadings for the Proposed Model:}

Due to the path loading for all factors must exceed the value of (0.55), all factors were accepted for analysis (Falk and Miller, 1992). Figure (1) details five individual aspects, namely performance standards (PS), Communication standards (CS), Comparing actual performance with employee standards and giving feedback (CF), Corrective action (CoA) and Employee Performance (EP). The author also provides an overview of the path loading results for all of the items linked with the recommended model in this research.

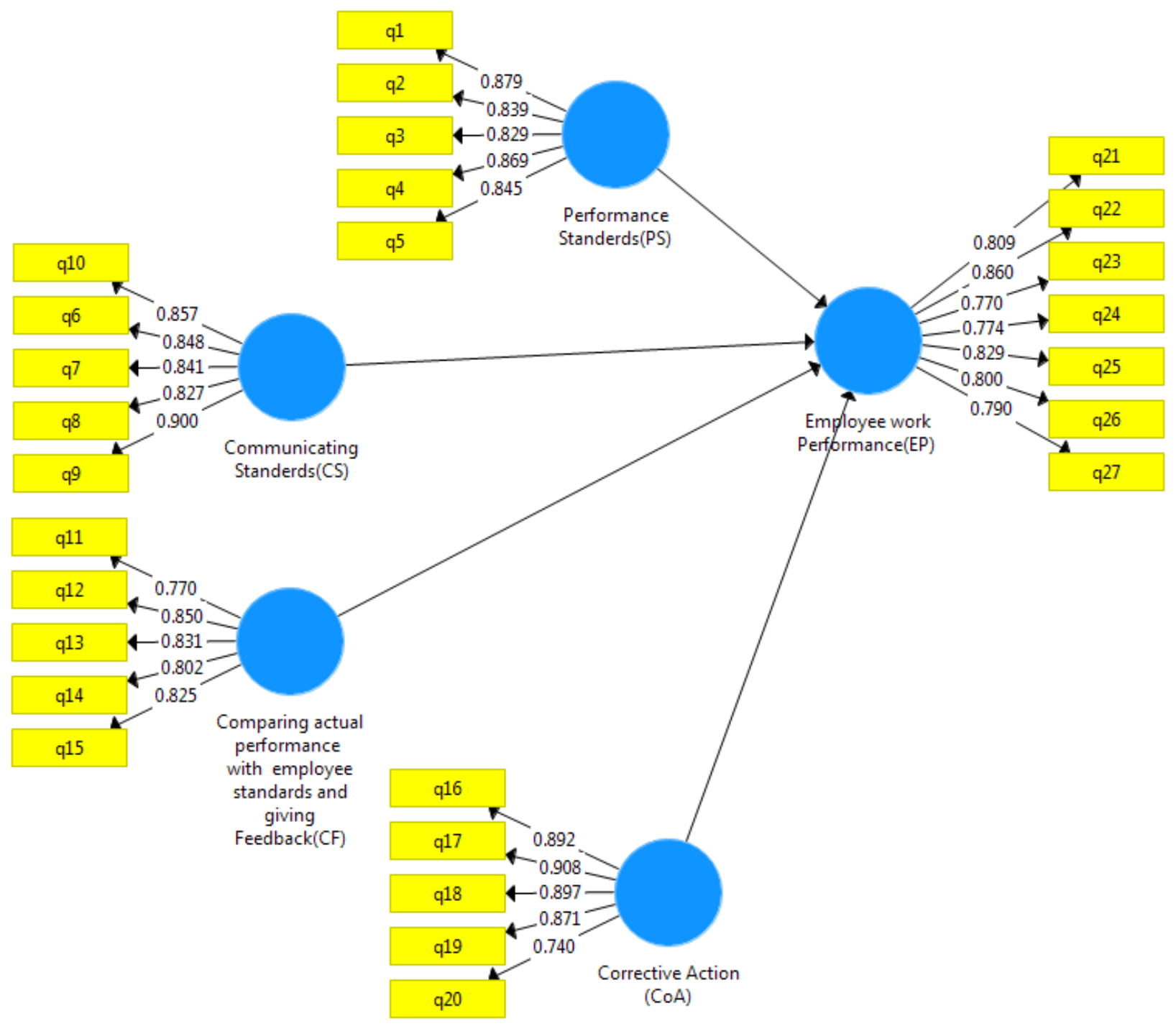

Figure 1. Path loading for Research model

\section{Research quality standards:}

\section{Reliability and Validity Test:}

Reliability is the extent to which the data collection method will yield consistent findings.

While, Validity ensures that the findings measure what is meant to be measured while checking the relationship between two variables (Mufleh,2016). 
In order to ensure the items in the questionnaire are both valid and reliable, Table (2) presents an explanation to Cronbach's Alpha, Composite Reliability, and Average Variance Extracted results for the entire model variables.

Table (2). Validity and reliability results

\begin{tabular}{|c|c|c|c|}
\hline Constructs & $\begin{array}{l}\text { Cronbach } \\
\text { Alpha (CA) }\end{array}$ & $\begin{array}{l}\text { Average } \\
\text { Variance } \\
\text { Extracted } \\
\text { (AVE) }\end{array}$ & $\begin{array}{l}\text { Composite } \\
\text { Reliability } \\
\text { (CR) }\end{array}$ \\
\hline Standard rates & $\begin{array}{l}\text { More than } \\
0.65 \\
\text { (Nunnally and } \\
\text { Bernstein, } \\
\text { 1994). }\end{array}$ & $\begin{array}{l}\text { More than } \\
0.50 \\
\text { (Fornell and } \\
\text { Larcker, } \\
\text { 1981) }\end{array}$ & $\begin{array}{l}\text { More than } \\
0.65 \\
\text { (Nunnally and } \\
\text { Bernstein, } \\
\text { 1994). }\end{array}$ \\
\hline Performance standards (PS) & 0.908 & 0.731 & 0.931 \\
\hline $\begin{array}{l}\text { Communication standards } \\
(\mathrm{CS})\end{array}$ & 0.906 & 0.727 & 0.930 \\
\hline $\begin{array}{l}\text { Comparing actual } \\
\text { performance with employee } \\
\text { standards and feedback (CF) }\end{array}$ & 0.874 & 0.666 & 0.909 \\
\hline Corrective action (CoA) & 0.913 & 0.747 & 0.936 \\
\hline Employee Performance (EP). & 0.909 & 0.648 & 0.928 \\
\hline
\end{tabular}

\section{Discriminate Validity Test:}

Latent Variable Correlation results are carried to establish discriminant validity, which implies that there is a need for a construct to share a larger portion of variance with its measures as opposed to any other construct incorporated within a specific model (Fornell and Larcker, 1981). The Latent Variable Correlations (Discriminant validity) findings are seen in the following table (3), which details all variables and shows that they illustrate a significant degree of variance when compared with other variables. Discriminate validity was statistically acceptable, with no occurrence of a correlation coefficient that exceeds 1.0; this ensures there is no presence of multicollinearity between variables. Essentially, if a correlation coefficient is seen to be more than 1.00, this would highlight a problem in multicollinearity (Hair et al., 2006). 
Table (3). Discriminate validity

\begin{tabular}{|c|c|c|c|c|c|}
\hline & 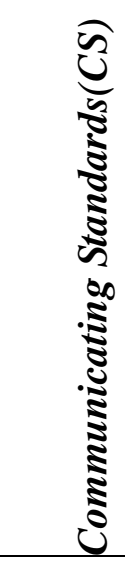 & 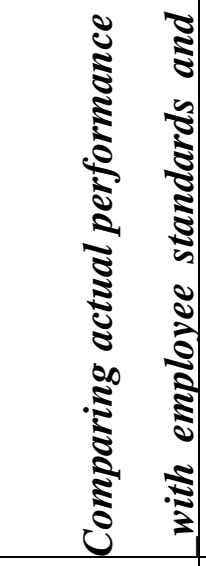 & 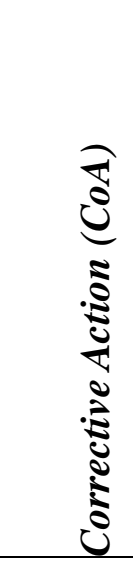 & 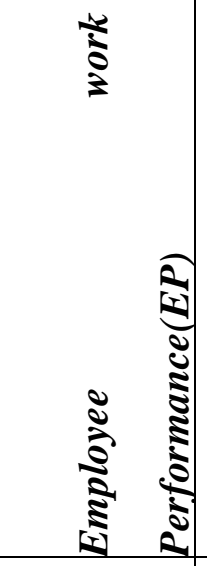 & 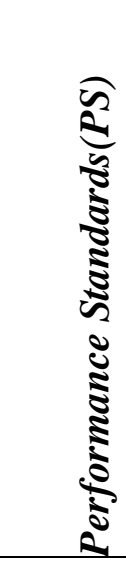 \\
\hline $\begin{array}{l}\text { Communication } \\
\text { Standards(CS) }\end{array}$ & 0.855 & & & & \\
\hline $\begin{array}{l}\text { Comparing actual } \\
\text { performance } \quad \text { with } \\
\text { employee standards and } \\
\text { giving Feedback }(\mathrm{CF})_{-}\end{array}$ & 0.860 & 0.816 & & & \\
\hline Corrective Action (CoA) & 0.810 & 0.867 & 0.864 & & \\
\hline $\begin{array}{ll}\text { Employee } & \text { work } \\
\text { Performance }(\text { EP }) & \end{array}$ & 0.849 & 0.857 & 0.821 & 0.805 & \\
\hline $\begin{array}{l}\text { Performance } \\
\text { Standards }(P S)\end{array}$ & 0.867 & 0.799 & 0.758 & 0.789 & 0.853 \\
\hline
\end{tabular}

\section{$R$ (Square) Test:}

The use of the $\mathrm{R}$ (Square) test is recognized as reasonable in explaining measurements and their interpretation. Table 4 gives an overview of the $\mathrm{R}$ (Square) value. The $\mathrm{R}$ (Square) value in current research shows the extent of interpretation from performance appraisal dimensions to employee work performance, the score is seen within an acceptable prediction level and equal to 0.796 , when it surpasses $25 \%$, as noted in the study of Gaur and Gaur (2006). 
Table 4. R (Square) value

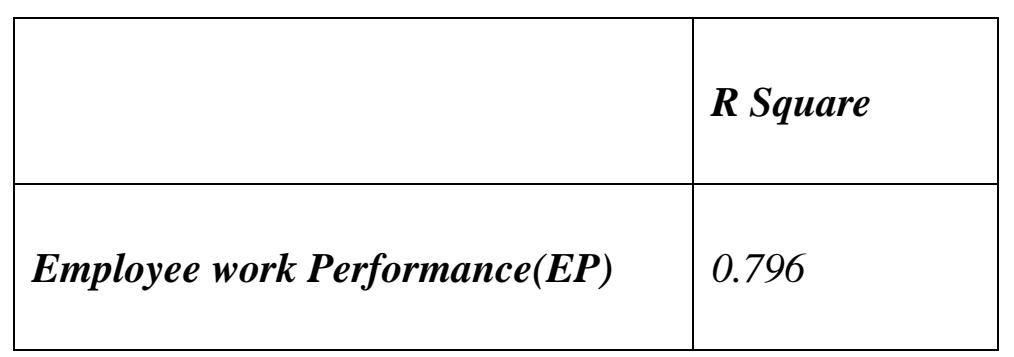

\section{Hypotheses Testing:}

The researchers accomplished a reasonable analysis, this was done in order to present a sound conclusion pertaining to the findings and relating to the hypotheses; this is facilitated through the application of bootstrapping analysis in smart PLS software. As can be seen in the completion of the test, the $\mathrm{p}$ value rate for all performance appraisal factors on employee work performance has been determined, as shown in Figure (2).

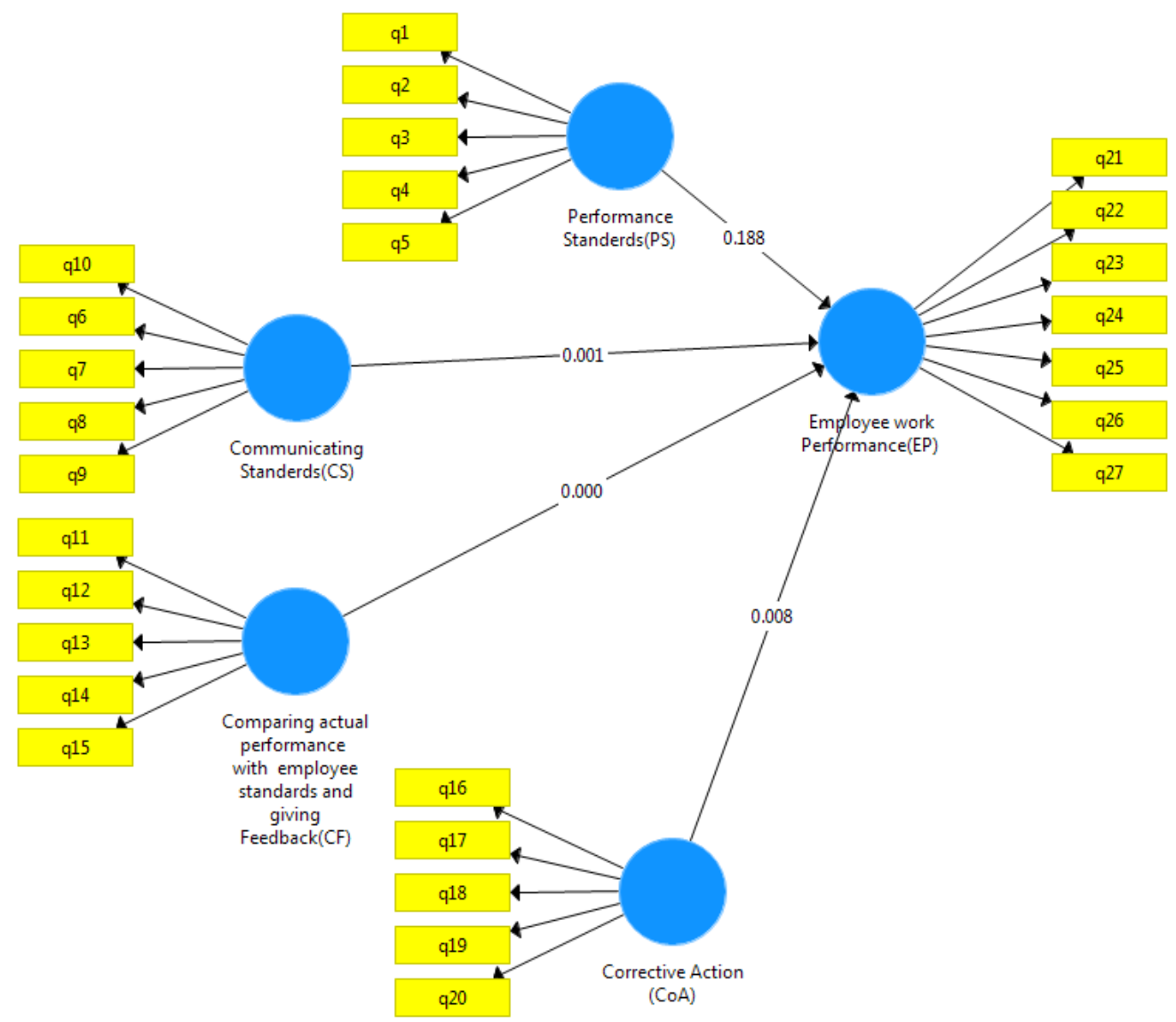

Figure (2). Bootstrapping (p-value) for for all performance appraisal factors on employee work performance in the Jordanian banking sector

Figure (2) displays the p-value rate, with the figure emphasizing the hypotheses testing in regards the four variables of performance appraisal: performance standards (PS), Communication standards (CS), Comparing actual performance, with employee standards 
and feedback (CF), Corrective action (CoA) and Employee Performance (EP), Table ( 5 ) provides an overview of the results.

Table (5). Test results of performance appraisal factors on employee work performance in the Jordanian bank sector

\begin{tabular}{|c|c|c|c|}
\hline $\begin{array}{l}\text { Relation } \\
\text { (direct effect) }\end{array}$ & $\begin{array}{l}\text { T } \\
\text { value }\end{array}$ & $\begin{array}{l}\text { Beta } \\
\text { value }\end{array}$ & $\begin{array}{l}\mathbf{p} \\
\text { value }\end{array}$ \\
\hline $\begin{array}{l}\text { Performance standards (PS) and } \\
\text { Employee Performance (EP) }\end{array}$ & 1.320 & 0.093 & 0.188 \\
\hline $\begin{array}{l}\text { Communication standards (CS) and } \\
\text { Employee Performance (EP) }\end{array}$ & 3.418 & 0.317 & 0.001 \\
\hline $\begin{array}{ll}\text { Comparing actual performance, with } \\
\text { employee standards and giving } \\
\text { feedback } \quad(\mathrm{CF}) \text { and Employee } \\
\text { Performance }(\mathrm{EP})\end{array}$ & 3.691 & 0.333 & 0.000 \\
\hline $\begin{array}{l}\text { Corrective action (CoA) and Employee } \\
\text { Performance (EP) }\end{array}$ & 2.682 & 0.205 & 0.008 \\
\hline
\end{tabular}

As detailed in Table (5), the H1.1 results emphasize that the performance standards (PS) do not influence Employee Performance (EP) in the Jordanian banking sector at $(\alpha \leq 0.05)$. In regards the statistics $\mathrm{T}$ value, this was determined to be (1.320), whereas the (Beta) Value ratio was (0.093).

Moreover, H1.2 results show that Communication standards (CS) influences Employee Performance (EP) in the Jordanian banking sector at $(\alpha \leq 0.05)$, with the statistics $\mathrm{T}$ value recognized as (3.418), whereas the (Beta) Value ratio was (0.317). This gives a clear outline as to the change of one amount of communication standards (CS) ability to induce a change equal to $(31.7 \%)$ in Employee Performance (EP). As such, it can be noted that communication standards (CS) positively influences Employee Performance (EP) in the Jordanian banking sector

In addition to, H1.3 results show that Comparing actual performance, with employee standards and giving feedback (CF) influences Employee Performance (EP) in the Jordanian banking sector at $(\alpha \leq 0.05)$, where the statistics $T$ value was determined to be (3.691), whereas the (Beta) Value ratio was seen to be (0.333); this provides a clear outline as to the change of one amount of Comparing actual performance, with employee standards and giving feedback (CF) as inducing a change equal to (33.3\%) in Employee Performance (EP).

As such, it can be noted that comparing actual performance, with employee standards and giving feedback (CF) positively influences Employee Performance (EP) in the Jordanian 
banking sector.

Finally, H1.4 results show that Corrective action (CoA) influences Employee Performance (EP) in the Jordanian banking sector at $(\alpha \leq 0.05)$, where the statistics $\mathrm{T}$ value was determined to be (2.682), whereas the (Beta) Value ratio was seen to be (0.205); this provides a clear outline as to the change of one amount of Corrective action (CoA) as inducing a change equal to $(20.5 \%)$ in Employee Performance (EP). As such, it can be noted that Corrective action (CoA) positively influences Employee Performance (EP) in the Jordanian banking sector.

\section{Conclusion}

1. There is a positive impact of employees work performance, on performance appraisal with significance of $5 \%$.

2. There is a negative impact of establishing performance standards on employee work performance with a significance of $5 \%$.

3. There is a negative impact of established communication standards on employee work performance with a significance of $5 \%$.

4. There is a positive impact of measuring actual performance and comparing it with standards on employee work performance with a significance of $5 \%$.

5. There is a positive impact of corrective action on employee work performance with a significance of $5 \%$.

\section{Recommendations}

In view of the above results, we recommend:

1 - There is a need to keep pace with performance appraisal systems such as cards to measure the performance of workers in banks operating in the South of Jordan.

2. There should be a focus on other more sensitive dimensions such as training and development to measure performance.

3. There needs to be more studies on performance evaluation and its impact on performance measurement in the South of Jordan.

4. Based on the results, there was a negative impact of performance standards on employee work performance in the banking sector in the South of Jordan, the employees in this sector prefer to have more freedom in their work while following specific standards that may increase their productivity.

\section{References}

Acuff, F. L. (2008). How to negotiate anything with anyone anywhere around the world. Amacom. 
Anderson, J. C., \& Gerbing, D. W. (1988). Structural equation modeling in practice: A review and recommended two-step approach. Psychological bulletin, 103(3), 411. https://doi.org/10.1037/0033-2909.103.3.411

Armstrong. (2006). (Handbook of Human Resource Management Practice (C) Michael new york: Mc Graw Hill Book $\quad$ Co. $\quad$ ISBN $978 \quad 0 \quad 7494 \quad 6964$. https://doi.org/10.1108/ijppm.2013.07962aaa.003

Cones, T. \& Jenkins, M. (2000). Abolishing Performance Appraisals. San Francisco, CA:Berrett-Koehler Publishers, Inc. https://doi.org/10.1057/9781137347503.0005

Daoanis, L. (2012).Performance Appraisal System: It's Implication To Employee Performance. International Journal of Economics and Management Sciences, 3, 55-62. https://doi.org/10.1108/ijppm.2013.07962aaa.003

De Waal, A. (2007). Strategic Performance Management, a Managerial and Behavioural Approach, Palgrave Macmillan. London p 120. https://doi.org/10.1057/9780230361553.0026

Falk, R. F., \& Miller, N. B. (1992). A primer for soft modeling. University of Akron Press.

Foot and hook. (2011.) Introducing Human Resource Management: Pearson Education Limited.

Fornell, C., \& Larcker, D. (1981). Evaluating structural equations models with unobservable variables and measurement error . Journal of Marketing Research, 1, 39-50. https://doi.org/10.1177/002224378101800312

Gaur, A., \& Gaur, S. (2006). Statistical Methods for Practice and Research: A Guide to Data Analysis using SPSS. California: 1 ed, Thousand Oaks, Sage Publications. https://doi.org/10.4135/9788132108306.n2

Giangreco, A., Carugati, A., Sebastiabo, A., \& Al Tamimi, H. (2012). War outside, ceasefire Inside: An analysis of the performance Appraisals system of a public hospital in a zone of conflict. Evaluation and Program planning, 1, 161-170. https://doi.org/10.1016/j.evalprogplan.2010.11.004

Gilliland, W., \& Langdon, C. (1998). Creating performance management systems that promote perceptions of Fairness. In J. W. Smither (Ed.), Performance appraisals: A state of the art in practice, pp.209-243. San Francisco: Josey-Bass.

Girma, T., Solomon, L., \& Gebre, S. (2016). The Effect of Performance Appraisal On Employee Performance: A Survey On Administrative Staff Of Hawassa University. IOSR Journal of Business and Management (IOSR-JBM), 3, 36-44. https://doi.org/10.1037/t46066-000

Gomez, M., David, B., \&Robert, L. (2001). Managing Human Resources .prentice hall, 3th ed. pp: 621. https://doi.org/10.1201/9781420040593

Hair, J., Black, B., Anderson, R., \& Tatham, R. (2006). Multivariate Data Analysis. NewJersey: Pearson Prentice Hall 6 ed. 
Jabeen, M. (2011).Impact of Performance Appraisal on Employees Motivation. European Journal of Business and Management, 3(4). https://doi.org/10.12816/0019382

Judge, T. A., \& Ilies, R. (2002). Relationship of personality to performance motivation: A meta-analytic review. Journal of applied psychology, 87(4), 797. https://doi.org/10.1037/0021-9010.87.4.797

Karimi, M., Hosseinzadeh, N., Hosseini, F., Kazem, N., \& Kazem, H. (2011). Seismic Evaluation of Pipe Rack Supporting Structures in a Petrochemical Complex in Iran. IJASE, $3(1), 112$.

Khan, A., Saha, G., \& Pal, R. K. (2018). An approach for reduction of false predictions in reverse engineering of gene regulatory networks. Journal of theoretical biology, 445, 9-30. https://doi.org/10.1016/j.jtbi.2018.02.015

Kumari, N., \& Malhotra, R. (2012). Effective Performance Management System for Enhancing Growth. Global Management Journal, 4, 77-85. https://doi.org/10.1007/978-3-642-29244-6_8

Mondy, \& Noe. (2005). Smart Talent Management: Building Knowledge Assets for Competitive Advantage. prentice hall, ed9. p252, https://doi.org/10.1108/14754390580000819

Mufleh, M. (2016). Research Methods Review In The Knowledge Management(Km) and Total Quality Management(Tqm) Studies. IJRRAS,3,87-101.

Mwema, N., \&Gachunga, G. (2014). The Influence of Performance Appraisal on Employee Productivity. International Journal of Social Sciences and Entrepreneurship, 1, 1-14.

Ramous Agyare, G. Y., Mensah, L., Aidoo, Z., \& Ansah, I. O. (2016). Impacts of performance appraisal on employees' job satisfaction and organizational commitment: A case of microfinance institutions in Ghana. International Journal of Business and Management, 11(9), 281-297. https://doi.org/10.5539/ijbm.v11n9p281

Roberts, G. E. (2003). Employee performance appraisal system participation: A technique that works. Public personnel management, 32(1), 89-98. https://doi.org/10.1177/009102600303200105

Sajuyigbe \& Ademola, S. (2017). Impact of Performance Appraisal on Employee Performance in Nigerian Telecommunication Industry (A study of MTN, Nigeria). IIARD International Journal of Economics and Business Management ISSN, 1, 2489-0065. https://doi.org/10.18775/ijmsba.1849-5664-5419.2014.46.1001

Swanepoel, B., Erasmus, B. J., \& schenk, H. W. (1998). South African Human Resource Management: Theory and Practice. South Africa: JUTA\& Co. Ltd, 4th ed. https://doi.org/10.1108/ijppm.2013.07962aaa.003

Weick, K., \& Sutcliffe, K. (2014). Managing the Unexpected: Assuring High Performance in an Age of Complexity. university of Michigan business school. 


\section{Copyright Disclaimer}

Copyright for this article is retained by the author(s), with first publication rights granted to the journal.

This is an open-access article distributed under the terms and conditions of the Creative Commons Attribution license (http://creativecommons.org/licenses/by/4.0/). 